\title{
PENGARUH KECERDASAN INTELEKTUAL PADA PEMAHAMAN AKUNTANSI DENGAN KECERDASAN EMOSI DAN KECERDASAN SPIRITUAL SEBAGAI VARIABEL PEMODERASI
}

\author{
Nyoman Suadnyana Pasek* \\ Universitas Pendidikan Ganesha, Jalan Udayana No. 11, Singaraja, Bali - \\ Indonesia \\ *(mang_suadnyana@yahoo.com)
}

\begin{abstract}
ABSTRAK
Penelitian ini bertujuan untuk mengetahui pengaruh kecerdasan intelektual pada tingkat pemahaman akuntansi, yang dimoderasi oleh kecerdasan emosional dan kecerdasan spritual. Metode penelitian yang digunakan dalam penelitian ini adalah explanatory research, yang akan menjelaskan hubungan kausal antara variabel independen tersebut terhadap variabel dependen dengan dua variabel pemoderasi. Pengumpulan data dilakukan melalui kuesioner dan data sekunder. Sedangkan analisis data yang digunakan meliputi analisis deskriptif, uji asumsi klasik dan analisis verifikatif dengan menggunakan Moderated Regression Analysis (MRA). Berdasarkan hasil penelitian dapat diketahui bahwa (1) Kecerdasan intelektual berpengaruh positif dan signifikan terhadap pemahaman akuntansi. Artinya dengan kecerdasan intelektual yang baik maka mahasiswa akan lebih mudah memahami tentang pemahaman akuntansi, (2) Kecerdasan emosional dapat meningkatkan pengaruh kecerdasan intelektual pada tingkat pemahaman akuntansi secara positif dan signifikan. (3) Kecerdasan spiritual dapat meningkatkan pengaruh kecerdasan intelektual pada tingkat pemahaman akuntansi secara positif dan signifikan.
\end{abstract}

Kata kunci: Kecerdasan Intelektual, Kecerdasan Emosional, Kecerdasan Spiritual, Pemahaman Akuntansi

\begin{abstract}
This study aims to reveal the effect of the intellectual at the level of understanding of accounting, moderating by emotional intelligence and spiritual intelligence. The method used in this research is explanatory research, which would explain the causal relationship between the independent variable on the dependent variable that is reinforced by moderating variables through hypothesis testing. Data collected through questionnaires and secondary data. While the data analysis includes descriptive analysis, the classical assumption test and verification analysis using Moderated Regression Analysis (MRA).Based on the results of this research is that (1) the intellectual positive and significant impact on the understanding of accounting. This means that with good intelligence quotient, the student will be easier to understand about the understanding of accounting, (2) Emotional intelligence can enhance intellectual influence on the level of understanding of accounting is positive and significant. (3) Spiritual intelligence Can enhance intellectual influence on the level of understanding of accounting is
\end{abstract}


positive and significant. Therefore, someone who has a high spiritual intelligence will also motivate students to study harder and have higher creativity.

Keywords: Intellectual Intelligence, Emotional Intelligence, Spiritual Intelligence, Understanding Accounting

\section{PENDAHULUAN}

Penyelenggaraan pendidikan akuntansi di perguruan tinggi ditujukan untuk mendidik mahasiswa agar menghasilkan mahasiswa yang berkompeten nantinya sebagai seorang akuntan professional. Menurut Mawardi (2011), salah satu cara agar dapat menghasilkan lulusan yang berkualitas adalah dengan cara meningkatkan kualitas sistem pendidikan. Pengetahuan yang dibutuhkan untuk akuntan terdiri dari pengetahuan umum, organisasi, bisnis, dan akuntansi (Hariyoga dan Edi, 2011). Pengetahuan mengenai dasar-dasar akuntansi tentunya akan dijadikan sebagai pegangan untuk memahami teori dan praktik akuntansi tersebut.Namun, hal ini berbanding terbalik dengan realita yang ada yaitu pendidikan akuntansi di perguruan tinggi saat ini hanya terkesan sebagai pengetahuan yang berorientasi pada mekanisme secara umum saja sedangkan apabila dibandingkan dengan praktik sesungguhnya din dunia kerja sangat berbeda.
Dwirandra (2013) menyatakan bahwa kalangan pengusaha dan industriawan tidak hanya meragukan kompetensi akuntan tetapi juga sikap etisnya. Keraguan terhadap kompetensi akuntan didasarkan pada kenyataan adanya beberapa kejahatan korperasi besar dan mendunia yang mengaitkan profesi ini. Yani (2011) menyatakan kecerdasan intelektual merupakan kecerdasan yang sangat dibutuhkan dalam keberhasilan seseorang, kecerdasan intelektual tetap mempengaruhi pola fikir seorang mahasiswa karena kecerdasan intelektual merupakan kecerdasan pertama yang dikembangkan yang mampu membuat seorang mahasiswa berfikir secara rasional untuk belajar akuntansi dan memahaminya.

Penelitian Yani (2011) ini menyimpulkan kecerdasan intelektual berpengaruh pada tingkat pemahaman akuntansi. Hasil penelitian Yani (2011) ini didukung oleh hasil penelitian Ardana et al. (2013) yang menyimpulkan kecerdasan intelektual

(IQ) 
berpengaruh positif pada tingkat pemahaman akuntansi.

Menurut Goleman (2003)

kecerdasan emosional mampu memberikan rasa empati, cinta, motivasi dan kemampuan untuk menangapi kesedihan atau kegembiraan secara tepat. Jika keterampilan emosional seseorang bisa berkembang dengan baik, maka tentunya ia dan berhasil mengembangkan kecerdasan intelektualnya untuk semakin berprestasi. Sebaliknya bila ia tidak memiliki kendali akan kehidupan emosionalnya tentunya ia akan mengalami pertarungan batin yang bisa mempengaruhi perilaku belajar dalam memahami akuntansi (Dwijayanti, 2009).

Untuk memfungsikan kecerdasan intelektual secara efektif maka diperlukannya kecerdasan spiritual. Jika seseorang memiliki kecerdasan spiritual yang tinggi maka tentunya hal tersebut akan memotivasi seseorang untuk lebih giat belajar dan menigkatkan kretivitasnya. Melakukan segala cara untuk mendapatkan nilai yang baik, sehingga tingkat pemahaman dalam akuntansi menjadi kurang bisa terjadi apabila seseorang kurang memiliki kecerdasan spiritual.

Pada penelitian terdahulu ditemukan beberapa hasil yang berbeda dalam meneliti pengaruh kecerdasan intelektual, kecerdasan emosional dan kecerdasan spiritual pada pemahaman akuntansi, diantaranya pada kecerdasan intelektual yaitu penelitian Yani (2011) yang menyatakan bahwa kecerdasan intelektual berpengaruh pada pemahaman akuntansi. Hasil penelitian ini mendukung hasil penelitian Veenman et al. (2004).

Namun hasil tersebut tidak konsisten dengan peneliti Dwijayanti (2009). Sedangkan untuk kecerdasan emosional hasil yang berpengaruh pada pemahaman akuntansi ditemukan penelitian Rachmi (2010), Yani (2011), Durgut et al. (2013) dan Amram (2009). Hasil berbeda ditemukan pada penelitian Trisnawati dan Suryaningrum (2003).

Selanjutnya, hasil penelitian yang dilakukan oleh Rachmi (2010) yang menyatakan bahwa kecerdasan spiritual berpengaruh terhadap pemahaman akuntansi. Hasil penelitian ini mendukung hasil penelitian McGhee dan Grant (2008), Oskou (2013) dan Clarken (2010). Namun hasil penelitian tersebut bertolak belakang dengan hasil penelitian yang dilakukan oleh Dwijayanti (2009) dan Yani (2011).

Berdasarkan inkonsistensi hasil penelitian pengaruh langsung kecerdasan intelektual, kecerdasan 
emosional dan kecerdasan spiritual baik secara individual maupun secara serentak, telah mendorong dilakukannya penelitian yang menempatkan kecerdasan emosional dan kecerdasan spiritual sebagai variabel pemoderasi dari pemahaman akuntansi. Peneliti ingin menguji kembali pengaruh kecerdasan intelektual pada pemahaman akuntansi Program S1 Akuntansi Undiksha Singaraja.

\section{TELAAH LITERATUR DAN PERUMUSAN HIPOTESIS}

\section{Pemahaman Akuntansi}

Melandy dan Aziza (2006), pemahaman akuntansi merupakan suatu kemampuan seorang untuk mengenal dan mengerti tentang akuntansi. Pemahaman akuntansi ini dapat di ukur dari nilai mata kuliah yang meliputi Pengantar Akuntansi, Akuntansi Keuangan Menengah 1, Akuntansi Keuangan Menengah 2, Akuntansi Keuangan Lanjutan 1, Akuntansi Keuangan Lanjutan 2, Auditing 1, Auditing 2, Auditing 3, dan Teori Akuntansi. Mata kuliah tersebut merupakan mata kuliah yang di dalamnya terdapat unsurunsur yang menggambarkan akuntansi secara umum.

\section{Kecerdasan Intelektual}

Kecerdasan intelektual (IQ) Merupakan pengkualifikasian kecerdasan manusia yang didominasi oleh kemampuan daya pikir rasional dan logika. Lebih kurang 80\%, IQ diturunkan dari orangtua, sedangkan selebihnya dibangun pada usia sangat dini yaitu 0-2 tahun kehidupan manusia yang pertama. Sifatnya relatif digunakan sebagai predictor keberhasilan individu dimasa depan. Implikasinya, sejumlah riset untuk menemukan alat (tes IQ) dirancang sebagai tiket untuk memasuki dunia pendidikan sekaligus dunia kerja (Amran, 2009).

Dwijayanti (2009) menyebutkan kecerdasan intelektual sebagai suatu kemampuan yang terdiri dari tiga ciri yaitu: a) Kemampuan untuk mengarahkan pikiran atau mengarahkan tindakan, b) Kemampuan untuk mengubah arah tindakan bila tindakan itu telah dilakukan, c) Kemampuan untuk mengkritik diri sendiri.

Robins dan Judge (2008) mengatakan bahwa kecerdasan Intelektual adalah kemampuan yang di butuhkan untuk melakukan berbagai aktivitas mental berpikir, menalar dan memecahkan masalah. Yani (2011) mengatakan bahwa kecerdasan intelektual adalah kemampuan untuk memperoleh, 
memanggil kembali (recall), dan menggunakan pengetahuan untuk memahami konsep-konsep abstrak maupun konkret dan hubungan antara objek dan ide, serta menerapkan pengetahuan secara tepat. Kecerdasan intelektual menurut Sternberg (2008) adalah sebagai kemampuan untuk belajar dari pengalaman, berfikir menggunakan proses-proses metakognitif, dan kemampuan untuk beradaptasi dengan lingkungan sekitar.

Kecerdasan

merupakan

intelektual kemampuan menganalisis, logika dan rasio seseorang. Dengan demikian, hal ini berkaitan dengan keterampilan bicara, kecerdasan akan ruang, kesadaran akan sesuatu yg tampak, dan penguasaan matematika. IQ mengukur kecepatan kita untuk mempelajari hal-hal baru, memusatkan perhatian pada aneka tugas dan latihan, menyimpan dan mengingat kembali informasi objektif, terlibat dalam proses berfikir, bekerja dengan angka, berpikir abstrak dan analitis, serta memecahkan masalah dan menerapkan pengetahuan yg telah ada sebelumnya. (Anastasi, 2007).

Berdasarkan beberapa definisi di atas, peneliti berpendapat bahwa kecerdasan intelektual merupakan kemampuan seseorang untuk memperoleh pengetahuan, menguasai dan menerapkannya dalam menghadapi masalah.

\section{Kecerdasan Emosional}

Goleman (2005) menyatakan bahwa kemampuan akademik bawaan, nilai rapor, dan prediksi kelulusan pendidikan tinggi tidak memprediksi seberapa baik kinerja seseorang sudah bekerja atau sebarapa tinggi sukses yang dicapainya dalam hidup. Goleman (2005) menyatakan bahwa seperangkat kecakapan khusus seperti empati, disiplin diri, dan inisiatif mampu membedakan orang sukses dari mereka yang berprestasi biasa-biasa saja, selain kecerdasan akal yang mempengaruhi keberhasilan orang dalam bekerja.

Goleman (2005) mendefinisikan kecerdasan emosional adalah kemampuan mengenali perasaan diri sendiri dan perasaan orang lain, memotivasi diri sendiri, serta mengelola emosi dengan baik pada diri sendiri dan dalam hubungan dengan orang lain. Rachmi (2010:31) mendefinisikan kecerdasan emosional sebagai kemampuan merasakan, memahami, dan secara efektif menerapkan daya dan kepekaan emosi sebagai sumber energi, informasi, koneksi dan pengaruh 
yang manusiawi. Kecerdasan emosi menuntut seseorang untuk relajar mengakui, menghargai perasaan diri sendiri dan orang lain serta menanggapinya dengan tepat dan menerapkan secara efektif energi emosi dalam kehidupan seharihari.

Melandy dan Aziza (2006) menyatakan bahwa, kecerdasan emosional adalah kecerdasan untuk menggunakan emosi sesuai dengan keinginan, kemampuan untuk mengendalikan emosi sehingga memberikan dampak yang positif. Kecerdasan emosional dapat membantu membangun hubungan dalam menuju kebahagiaan dan kesejahteraan.

Rachmi (2010) mendefinisikan kecerdasan emosional sebagai komponen yang membuat seseorang menjadi pintar menggunakan emosinya. Emosi manusia berada di wilayah dari perasaan lubuk hati, naluri yang tersembunyi dan sensasi emosi yang apabila diakui dan dihormati, kecerdasan emosional akan menyediakan pemahaman yang lebih mendalam dan lebih utuh tentang diri sendiri dan orang lain.

Melandy dan Aziza (2006) mendefinisikan kecerdasan emosional adalah kemampuan untuk mengenali perasaan, meraih dan membangkitkan perasaan untuk membantu pikiran, memahami perasaan dan maknanya, dan mengendalikan perasaan secara mendalam sehingga membantu perkembangan emosi. Berdasarkan beberapa pendapat di atas, peneliti berpendapat bahwa kecerdasan emosional menuntut diri untuk belajar mengakui dan menghargai perasaan diri sendiri dan orang lain dan untuk menanggapinya dengan tepat, menerapkan dengan efektif energi emosi dalam kehidupan dan pekerjaan sehari-hari.

Goleman (2005) membagi kecerdasan emosional menjadi lima bagian yaitu tiga komponen berupa kompetensi emosional (pengenalan diri, pengendalian diri dan motivasi) dan dua komponen berupa kompetensi sosial (empati dan keterampilan sosial). Lima komponen kecerdasan emosional tersebut adalah sebagai berikut:

a. Pengenalan Diri (Self Awareness) Pengenalan diri adalah kemampuan seseorang untuk mengetahui perasaan dalam dirinya dan digunakan untuk membuat keputusan bagi diri sendiri, memiliki tolak ukur yang realistis atas kemampuan diri dan memiliki kepercayaan diri yang kuat. Unsur-unsur kesadaran diri, yaitu kesadaran emosi, penilaian diri, dan percaya diri. 
b. Pengendalian Diri (Self Regulation). Pengendalian diri adalah kemampuan menangani emosi diri sehingga berdampak positif pada pelaksanaan tugas, peka terhadap kata hati, sanggup menunda kenikmatan sebelum tercapainya suatu sasaran, dan mampu segera pulih dari tekanan emosi. Unsur-unsur pengendalian diri, yaitu kendali diri, sifat dapat dipercaya, kehati-hatian, adaptabilitas, dan inovasi.

c. Motivasi (Motivation) Motivasi adalah kemampuan menggunakan hasrat agar setiap saat dapat membangkitkan semangat dan tenaga untuk mencapai keadaan yang lebih baik, serta mampu mengambil inisiatif dan bertindak secara efektif. Unsur-unsur motivasi, yaitu dorongan prestasi, komitmen, inisiatif, dan optimisme.

d. Empati (Emphaty) Empati adalah kemampuan merasakan apa yang dirasakan oleh orang lain. Mampu memahami perspektif orang lain dan menimbulkan hubungan saling percaya, serta mampu menyelaraskan diri dengan berbagai tipe individu. Unsur-unsur empati, yaitu memahami orang lain, mengembangkan orang lain, orientasi pelayanan, memanfaatkan keragaman, dan kesadaran politis.

e. Ketrampilan Sosial (Social Skills) Ketrampilan sosial adalah kemampuan menangani emosi dengan baik ketika berhubungan dengan orang lain, bisa mempengaruhi, memimpin, bermusyawarah, menyelasaikan perselisihan, dan bekerjasama dalam tim. Unsur-unsur keterampilan sosial, yaitu pengaruh, kemampuan untuk komunikasi, manajemen konflik, kepemimpinan, membangun hubungan, kolaborasi dan kooperasi, dan kemampuan tim.

\section{Kecerdasan Spiritual}

Kecerdasan spiritual ditemukan oleh Danah Zohar dan Ian Marshall pada pertengahan tahun 2000. Zohar dan Marshall (2007) menegaskan bahwa kecerdasan spiritual adalah landasan untuk membangun kecerdasan intelektual dan kecerdasan spiritual.

Rachmi (2010) mendefinisikan kecerdasan spiritual sebagai pikiran yang mendapat inspirasi, dorongan, efektivitas yang terinspirasi, dan penghayatan ketuhanan yang semua manusia menjadi bagian di dalamnya. 
Rachmi (2010) menyebutkan kecerdasan spiritual sebagai fakultas dimensi non-material atau jiwa manusia. Kecerdasan spiritual sebagai intan yang belum terasah dan dimiliki oleh setiap insan. Manusia harus mengenali seperti adanya lalu menggosoknya sehingga mengkilap dengan tekad yang besar, menggunakannya menuju kearifan, dan untuk mencapai kebahagiaan yang abadi.

Wahab dan Umiarso (2011) menyatakan kecerdasan spritual adalah kecerdasan yang sudah ada dalam setiap manusia sejak lahir yang membuat manusia menjalani hidup penuh makna, selalu mendengarkan suara hati nuraninya, tak pernah merasa sia-sia, semua yang dijalaninya selalu bernilai.

Ludigdo et al. (2006) menyatakan bahwa kecerdasan spiritual adalah kecerdasan untuk menghadapi dan memecahkan persoalan makna dan nilai, yaitu menempatkan perilaku dan hidup manusia dalam konteks makna yang lebih luas dan kaya, serta menilai bahwa tindakan atau hidup seseorang lebih bermakna dibandingkan dengan yang lain. Kecerdasan spiritual tidak mesti berhubungan dengan agama. Kecerdasan spiritual mendahului seluruh nilai spesifik dan budaya manapun, serta mendahului bentuk ekspresi agama manapun yang pernah ada. Namun bagi sebagian orang mungkin menemukan cara pengungkapan kecerdasan spiritual melalui agama formal sehingga membuat agama menjadi perlu.

Ginanjar (2005) mendefinisikan kecerdasan spiritual sebagai kemampuan untuk memberi makna ibadah terhadap setiap perilaku dan kegiatan melalui langkah-langkah dan pemikiran yang bersifat fitrah, menuju manusia yang seutuhnya dan memiliki pola pemikiran integralistik, serta berprinsip hanya karena Allah. Ginanjar (2005) menyebutkan kecerdasan Spiritual adalah kemampuan untuk memberi makna spiritual terhadap pemikiran, perilaku dan kegiatan, serta mampu menyinergikan IQ, EQ dan SQ secara komprehensif.

Prinsip-prinsip kecerdasan spiritual menurut Rachmi (2010: 44), yaitu:

a. Prinsip Bintang

Prinsip bintang adalah prinsip yang berdasarkan iman kepada Tuhan yang Maha Kuasa. Semua tindakan yang dilakukan hanya untuk Tuhan dan tidak mengharap pamrih dari orang lain dan melakukannya sendiri. 
b. Prinsip Malaikat (Kepercayaan) Prinsip malaikat adalah prinsip berdasarkan iman kepada Malaikat. Semua tugas dilakukan dengan disiplin dan baik sesuai dengan sifat malaikat yang dipercaya oleh Tuhan untuk menjalankan segala perintah Tuhan yang Maha Kuasa.

c. Prinsip Kepemimpinan

Prinsip kepemimpinan adalah Pada Agama Islam yaitu prinsip berdasarkan iman kepada Rasullullah SAW. Seorang pemimpin harus memiliki prinsip yang teguh, agar mampu menjadi pemimpin yang sejati. Seperti Rasullullah SAW adalah seorang pemimpin sejati yang dihormati oleh semua orang.

d. Prinsip Pembelajaran

$$
\text { Prinsip pembelajaran }
$$
adalah prinsip berdasarkan iman kepada kitab. Suka membaca dan belajar untuk menambah pengetahuan dan mencari kebenaran yang hakiki. Berpikir kritis terhadap segala hal dan menjadikan kitab suci sebagai pedoman dalam bertindak.

e. Prinsip Masa Depan Prinsip masa depan adalah prinsip yang berdasarkan iman kepada "hari akhir". Berorientasi terhadap tujuan, baik jangka pendek, jangka menengah maupun jangka panjang, disertai keyakinan akan adanya "hari akhir" dimana setiap individu akan mendapat balasan terhadap setiap tindakan yang dilakukan.

f. Prinsip Keteraturan

Prinsip keteraturan merupakan prinsip berdasarkan iman kepada "ketentuan Tuhan". Membuat semuanya serba teratur dengan menyusun rencana atau tujuan secara jelas. Melaksanakan dengan disiplin karena kesadaran sendiri, bukan karena orang lain.

Berdasarkan beberapa definisi di atas, peneliti berpendapat bahwa kecerdasan spiritual adalah kemampuan manusia memaknai bagaimana arti dari kehidupan serta memahami nilai tersebut dari setiap perbuatan yang dilakukan dan kemampuan potensial setiap manusia yang menjadikan seseorang dapat menyadari dan menentukan makna, nilai, moral, serta cinta terhadap kekuatan yang lebih besar dan sesama makhluk hidup karena merasa sebagai bagian dari keseluruhan, sehingga membuat manusia dapat menempatkan diri 
dan hidup lebih positif dengan penuh kebijaksanaan, kedamaian, dan kebahagiaan yang hakiki.. Zohar dan Marshall (2007: 14) menguji SQ dengan hal-hal berikut:

a. Kemampuan bersikap fleksibel yaitu mampu menempatkan diri dan dapat menerima pendapat orang lain secara terbuka.

b. Tingkat kesadaran diri yang tinggi seperti: kemampuan autocritism dan mengetahui tujuan dan visi hidup.

c. Kemampuan untuk menghadapi dan memanfaatkan penderitaan seperti: tidak ada penyesalan, tetap tersenyum dan bersikap tenang dan berdoa.

d. Kemampuan untuk menghadapi dan melampaui rasa sakit seperti: bersikap ikhlas dan pemaaf.

e. Kualitas hidup yang diilhami oleh visi dan nilai-nilai seperti: prinsip dan pegangan hidup dan berpijak pada kebenaran.

f. Keengganan untuk menyebabkan kerugian yang tidak perlu seperti: tidak menunda pekerjaan dan berpikir sebelum bertindak.

g. Kecenderungan untuk melihat keterkaitan antara berbagai hal yaitu berpandangan holistik seperti: kemampuan berfikir logis dan berlaku sesuai norma sosial.

h. Kecenderungan nyata untuk bertanya mengapa atau bagaimana jika untuk mencari jawaban-jawaban yang mendasar seperti: kemampuan berimajinasi dan keingintahuan yang tinggi.

i. Menjadi apa yang disebut oleh para psikolog sebagai bidang mandiri yaitu memiliki kemudahan untuk bekerja melawan konvensi, seperti: mau memberi dan tidak mau menerima.

\section{METODE}

Penelitian ini dilakukan di Program S1 Akuntansi Universitas Undiksha Singaraja. Populasi penelitian ini adalah seluruh mahasiswa Program S1 Akuntansi Universitas Undiksha Singaraja. Angkatan 2012, 2013 dan 2014 yang berjumlah 861 orang dengan teknik pengambilan random sampling yang menggunakan rumus slovin dan didapat sampel sejumlah 90 mahasiswa Jurusan Akuntansi Fakultas Ekonomi dan Bisnis Undiksha Singaraja. Pengumpulan data dilakukan dengan menggunakan kuesioner. Analsis data menggnakan analisis $M R A$. 
HASIL DAN PEMBAHASAN

Hasil uji kelayakan model (Uji F) dan Koefisien determinasi ditampilkan pada tabel 1. Berdasarkan Tabel 1 dapat diketahui bahwa model regresi memiliki P-value (Sig. F Change) sebesar 0,000 , nilai tersebut lebih kecil daripada a (5\%) sehingga dapat dikatakan bahwa model regresi tersebut memenuhi uji kelayakan model. Sejauh mana variasi perubahan variabel independen dalam model mampu menjelaskan variasi perubahan variabel dependennya dapat dilihat dari koefisien determinasi, dalam hal ini digunakan indikator R2. Besarnya koefisien Determinasi R2 masing-masing model regresi tanpa interaksi dan model regresi dengan interaksi dapat dilihat pada Tabel 2. Berdasarkan tabel tersebut dapat diketahui besarnya R2 model regresi tanpa interaksi sebesar 40,3\% sedangkan model regresi dengan interaksi sebesar 56,1\%, yang menjelaskan variasi perubahan variabel dependen sebesar 56,1\% sedangkan sisanya sebesar 43,9\% dijelaskan oleh variasi perubahan variabel independen di luar model.

Tabel 1. Hasil Uji Kelayakan Model (Uji F)

\begin{tabular}{ccccc}
\hline R Square Change & F Change & df1 & df2 & Sig. F Change \\
\hline 0,239 & 3,663 & 3 & 83 & 0,000 \\
\hline
\end{tabular}

Sumber: Output SPSS

Tabel 2, Koefisien determinasi

\begin{tabular}{ccccc}
\hline Model & $\mathrm{R}$ & $\mathrm{R}$ Square & $\begin{array}{c}\text { Adjusted R } \\
\text { Square }\end{array}$ & $\begin{array}{c}\text { Std. Erorr of } \\
\text { the estimate }\end{array}$ \\
\hline 1 & $0,635(\mathrm{a})$ & 0,403 & 0,400 & 167.929 \\
2 & $0,749(\mathrm{a})$ & 0,561 & 0,543 & 1.269 .843 \\
\hline
\end{tabular}

Sumber: Output SPSS

Hasil Moderated Regression Analysis (MRA) dapat diuraikan sebagai berikut (tabel 3).

\section{Pengaruh IQ terhadap PA}

Berdasarkan hasil analisis diketahui bahwa memperoleh hasil Pvalue sebesar 0,000 yang berarti lebih kecil dari level signifikansi sebesar 5\% atau 0,05. Ini berarti IQ berpengaruh positif pada tingkat PA. Hasil penelitian ini mendukung penelitian yang dilakukan oleh Yani (2011) ini didukung oleh hasil penelitian Ardana et al. (2013) yang menyimpulkan IQ berpengaruh positif dan signifikan pada tingkat PA. Yani (2011) menyatakan IQ merupakan kecerdasan yang sangat dibutuhkan dalam keberhasilan seseorang, IQ tetap mempengaruhi pola fikir 
seorang mahasiswa karena IQ merupakan kecerdasan pertama yang dikembangkan yang mampu membuat seorang mahasiswa berfikir secara rasional untuk belajar akuntansi dan memahaminya. Penelitian Yani (2011) ini menyimpulkan IQ berpengaruh pada tingkat PA.

Tabel 3. Analisis Regresi Pengaruh IQ terhadap PA yang dimoderasi oleh EQ dan SQ

\begin{tabular}{ccccc}
\hline \multirow{2}{*}{ Model } & \multicolumn{2}{c}{ Unstandardized Coefficients } & $\mathrm{t}$ & Sig. \\
\cline { 2 - 3 } & $\mathrm{B}$ & Std. Error & & 0,000 \\
\hline (Constant) & 17.046 & 2.018 & 9.447 & 0,000 \\
IQ & 0,464 & 0,039 & 6.421 & 0,000 \\
EQ & 0,356 & 0,021 & 4,267 & 0,003 \\
SQ & 0,362 & 0,034 & 3,758 & 0,000 \\
IQ-EQ & 0,729 & 0,060 & 7,281 & 0,000 \\
IQ-SQ & 0,726 & 0,073 & 7,203 & \\
\hline
\end{tabular}

Sumber: output SPSS

Menurut William Stren dalam Purwanto (2003), IQ adalah kesanggupan untuk menyesuaikan diri kepada kebutuhan baru, dengan menggunakan alat-alat berfikir yang sesuai dengan tujuan. Wechler dalam Pratiwi (2011) merumuskan IQ sebagai keseluruhan kemampuan individu untuk berpikir dan bertindak secara terarah serta kemampuan mengelola dan meguasai lingkungan secara efektif. Menurut Zohar dan Marshall (2007), semakin tinggi IQ seseorang, semakin tinggi pula kecerdasannya. Hal ini berarti apabila seorang seorang mahasiswa memiliki IQ yang baik tentunya akan memiliki kompetensi untuk memahami akuntansi.

\section{Pengaruh kemampuan IQ pada tingkat PA yang dapat diperkuat oleh EQ}

Berdasarkan hasil analisis diketahui bahwa hasil $\mathrm{P}$-value sebesar 0,000 yang berarti lebih kecil dari level signifikansi sebesar 5\% atau 0,05 . Berdasarkan hal tersebut dapat disimpulkan bahwa adanya SQ dapat memperkuat pengaruh IQterhadap PA. Zohar dan Marshall (2007) menyatakan bahwa SQ merupakan kecerdasan yang diperlukan seseorang untuk menentukan mana yang seharusnya dilakukan dan mana 
yang tidak seharusnya dilakukan. Apabila seorang mahasiswa memiliki SQ yang baik, tentunya ia akan memiliki motivasi untuk memahami akuntansi dan meraih nilai yang baik tanpa menggunakan cara-cara yang curang. Oleh karena itu pemahaman akan Akuntansi akan meningkat seiring dengan SQ yang dimiliki.

\section{KESIMPULAN, IMPLIKASI DAN KETERBATASAN PENELITIAN}

Berdasarkan pembahasan di atas, maka dapat disimpulkan hal-hal sebagai berikut, 1) Kecerdasan intelektual berpengaruh positif dan signifikan terhadap pemahaman akuntansi; 2) Kecerdasan emosional dan kecerdasan spiritual dapat meningkatkan pengaruh kecerdasan intelektual padatingkat pemahaman akuntansi secara positif dan signifikan.

Berdasarkan kesimpulan di atas, maka saran-saran yang dapat diberikan melalui hasil penelitian ini adalah sebagai berikut 1) Untuk meningkatkan kecerdasan intelektual dapat dilakukan dengan cara memberikan tugas-tugas yang bersifat studi kasus yang lebih menggambarkan praktek nyata dari ilmu akuntansi.; 2) Untuk meningkatkan kecerdasan emosional dapat dilakukan dengan cara antara lain dengan melatih mahasiswa agar dapat bekerja dalam team.; 3) Kecerdasan spiritual dapat ditingkatkan dengan cara antara lain dengan mengadakan seminar bertema keagamaan, puja bakti bersama dan kegiatan-kegiatan keagamaan lainnya.; 4) Penelitian selanjutnya diharapkan dapat meneliti lebih dalam tidak terbatas pada variabel kecerdasan intelektual, kecerdasan emosional, dan kecerdasan spiritual dalam kaitannya dengan pemahaman akuntansi, melainkan perlu adanya penambahan variabel lainnya serta diharapkan dapat menggunakan cakupan obyek penelitian yang lebih luas. Selain itu dalam penelitian lanjutan diharapkan dapat dikembangkan model analisis yang ada untuk mendapat hasil yang lebih mendalam.

\section{REFERENSI}

Amram, Joseph Yosi. 2009. The Contribution of Emotional and Spiritual Intelligences to Effective Business Leadership. Dissertation of Psychology of Institute of Transpersonal Psychology, Palo Alto, California.

Ardana, I Cenik, Lerbin R. Aritonang dan Elizabeth Sugiarto Dermawan. 2013. Kecerdasan Intelektual, Kecerdasan Emosional, Kecerdasan Spiritual, dan Kesehatan Fisik Untuk Memprediksi Prestasi Belajar Mahasiswa Akuntansi. Jurnal Akuntansi, Vol. XVII, No. 03, hlm. 444-458. 
Clarken, Rodney H. 2010. Considering Moral Intelligence as Part of a Holistic Education. Journal Education, Northern Michigan University.

Durgut, Mehmet, Bilal Gerekan, and Abdulkadir Pehlivan. 2013. The Impact of Emotional Intelligence on the Achievement of Accounting Subject. Jurnal of Business and Social Science, Vol. 4, No. 13.

Dwijayanti, A. P. 2009. Pengaruh Kecerdasan Emosional, Kecerdasan Intelektual. Kecerdasan Spiritual, dan Kecerdasan Sosial terhadap Pemahaman Akuntansi. Skripsi. Universitas Pembangunan Nasional "Veteran", Jakarta.

Dwirandra. 2013. Pengaruh Perilaku Belajar terhadap Tingkat Pemahaman Akuntansi dan Sikap Etis dengan Kecerdasan Emosional dan Kecerdasan Spiritual sebagai Variabel Pemoderasi.

Goleman, Daniel. 2003. Emotional Intelligence. Jakarta: PT Gramedia Pustaka Utama.

Hariyoga, Septian dan Suprianto, Edi. 2011. Pengaruh Kecerdasan Emocional, Perilaku Relajar, dan Budaza Terhadap Tingkat Pemahaman Akuntansi Dengan Kepercayaan Diri sebagai Variable Pemoderasi. Simposium Nasional Akuntansi XIV.

Marcel V.J. Veenman, Pascal Wilhelm, Jos J. Beishuizen. 2004. The Relation Between Intellectual and Metacognitive Skills from a Developmental Perspective. Jurnal Learning and Instruction, No. 13, 89-109.

Mawardi. M.Cholid. 2011. Tingkat Pemahaman Mahasiswa
Akuntansi Terhadap Konsep Dasar Akuntansi di Perguruan Tinggi di Kota Malang. Jurnal Akuntansi Fakultas Ekonomi Universitas Islam (UNISMA) Malang.

Patricia Grant, and Peter McGhee. 2008. Spirituality and Ethical Bahaviour in the Workplace: Wishful Thinking or Authentic Reality. Jurnal of Business Ethics and Organization Studies, Vol. 13, No. 2.

Rachmi, Filia. 2010. Pengaruh Kecerdasan Emosional, Kecerdasan Spiritual, dan Perilaku Belajar Terhadap Pemahaman Akuntansi Semarang. Jurnal Pendidikan Akuntansi.

Sugiyono. 2012. Metode Penelitian Kuantitatif, Kualitatif dan $R$ \& $D, \quad$ Bandung: Penerbit Alfabeta.

Vahid Oskou, Mohammad Reza Ashtiani, Mehdi Soltani, and Keivan Fathi. 2013. Investigation and Evaluation of Spiritual Intelligence: A Demographic Approach. Jurnal of Engineering and Applied Sciences, Vol. 3, No. 17.

Yani, Fitri. 2011. Pengaruh Kecerdasan Intelektual, Kecerdasan Emosional, Kecerdasan Spiritual Terhadap Pemahaman Akuntansi. Jurnal Akuntansi Pendidikan. Universitas Riau.

Zakiah, Farah. 2013. Pengaruh Kecerdasan Intelektual, Kecerdasan Emosional dan Kecerdasan Spiritual terhadap Pemahaman Akuntansi. Jurusan Akuntansi Fakultas Ekonomi Universitas Jember.

Zohar, D., dan Marshall, I. 2007. SQ: 
Pasek - Pengaruh Kecerdasan Intelektual pada Pemahaman ...

Memanfaatkan Kecerdasan

Spiritual dalam Berpikir

Integralistik dan Holistik untuk

Memaknai

Kehidupan.
Diterjemahkan oleh Rahmi Astuti, Ahmad Najib Burhani dan Ahmad Baiquni.

Bandung: Mizan. 